\title{
Intertidal water column meiofauna in relation to wave intensity on an exposed beach*
}

\author{
J. GERMÁN RODRÍGUEZ
}

Área de Ecoloxía, Facultade de Ciencias, Universidade de Vigo, 36200 Vigo, Spain. E-mail: german@uvigo.es

\begin{abstract}
SUMMARY: Since the 1970s, various studies have shown that some meiofaunal taxa frequently occur in the water column. Water currents or any process that disturbs the sediments are possible factors that can facilitate the passive entry of meiofauna in the water column. Wave action has been predicted as one of these factors (Armonies, 1994), suggesting a correlation between the number of eroded specimens and wave intensity should exist. As a test of this prediction, replicated samples were taken in the water column, swash sediment and back-swash water in an exposed beach (Island of Sylt, northern Wadden Sea). Wave height and period were measured to characterise the energy regime. Samplings were carried out over a nine day period in August 2000, at diurnal mid-tide time. Wave height and period varied significantly among collections. Densities of nematodes, harpacticoids, nauplii, platyhelminthes, ostracods and bivalve larvae in the water column, swash sediment and back-swash water varied significantly among collections. Nevertheless, no significant correlation was found between water column density and wave characteristics. Density of meiofauna in the water column was not correlated with density in the sediment or in back-swash water. Therefore wave intensity did not explain the variability of meiofaunal densities present in the water column.
\end{abstract}

Key words: meiofauna, hydrodynamics, exposed beach.

RESUMEN: MEIOFAuna DE LA COLUMNA DE AGUA INTERMAREAL EN RELACión CON LA INTENSIDAD DEL OLEAJE EN UNA PLAYA EXPUESTA. - Desde la década de 1970, diversos estudios han demostrado que algunos táxones de la meiofauna se encuentran con frecuencia en la columna de agua. Las corrientes, o cualquier proceso que perturbe los sedimentos, son factores posibles que pueden facilitar la entrada pasiva de meiofauna en la columna de agua. Se ha aventurado que la acción del oleaje es uno de tales factores (Armonies, 1994), lo que sugiere que debe existir una correlación entre el número de especímenes arrancados y la intensidad del oleaje. Para comprobar esta predicción, se tomaron muestras replicadas en la columna de agua, el sedimento arrastrado y el agua de resaca en una playa batida (isla de Sylt, mar de Wadden septentrional). Se midieron la altura y el período de la ola para caracterizar el régimen energético. Se tomaron muestras a lo largo de un período de nueve días en agosto de 2000, en el momento de las semimareas diurnas. La altura y el período de la ola variaron de manera significativa entre muestras. Las densidades de nemátodos, harpacticoides, nauplios, platelmintos, ostrácodos y larvas de bivalvos en la columna de agua, sedimento arrastrado y agua de resaca variaron de forma significativa entre muestras. No obstante, no se encontró ninguna correlación significativa entre densidad en la columna de agua y características del oleaje. La densidad de la meiofauna en la columna de agua no estaba correlacionada con la densidad en el sedimento o en el agua de resaca. Por ello, la intensidad del oleaje no explicaba la variabilidad de las densidades de la meiofauna presente en la columna de agua.

Palabras clave: meiofauna, hidrodinamismo, playa expuesta.

\section{INTRODUCTION}

High energy beaches are the most dynamic of soft-bottom habitats (McLachlan et al., 1996).

*Received September 19, 2001. Accepted June 10, 2003.
These harsh habitats harbour a diverse and abundant fauna, including meiofauna and macrofauna (McLachlan, 1983). Some species of this fauna can actively enter the water column or be passively eroded from the sediment (Brown and McLachlan, 1990; Armonies, 1994). In beaches and other 
soft-bottom habitats (salt marshes, sandflats and tidal creeks), biological and hydrodynamic factors play an important role in the passive entry of meiofauna into the water column (see Palmer, 1988 and Armonies, 1994 for reviews). Specific interactions and biotic sediment disturbance are the main biological factors (Armonies, 1994). Current velocity and the presence of aboveground structures are the main hydrodynamic factors (Eckman, 1983; Palmer, 1986; Palmer and Molly, 1986; Armonies, 1988a). In addition to these two hydrodynamic factors, Armonies (1994) indicated that wave action is also a factor potentially influencing passive water column entry of meiofauna, and in this regard he predicted a correlation between number of eroded specimens and wave height. This prediction is based on the fact that wave intensity (a combination of height and period) is positively correlated with sediment erosion rate (e.g. Short, 1999).

Exposed sandy beaches are appropriate habitats in which to examine Armonies's prediction, for two reasons: (1) in these extreme environments, the distribution and abundance of fauna are controlled primarily by physical elements (McLachlan, 1983), and (2) the hydrodynamic regime is dominated by waves (Short, 1999). The first characteristic minimises the possible influence of biological factors in the passive entry of meiofauna into the water column. The second feature minimises the influence of other possible hydrodynamic factors.

To test Armonies's prediction, this study was conducted to answer the question: are the meiofaunal densities in the water column and swash water correlated with wave characteristics in an exposed sandy beach? To check this, water and sediment samples were collected in an exposed sandy beach under different wave intensities.

\section{MATERIALS AND METHODS}

\section{Samplings}

An intertidal site of the exposed beach ListWest at the NW of the Island of Sylt (Germany, North Sea) was sampled for nine days between August 15th and August 31st 2000. A previous study (unpublished) at the sampling site (July 2000) characterised the intertidal grain size as coarse (sensu Folk, 1980), with an intertidal slope of $7^{\circ}$ and with a reflective morphodynamic state (sensu Short and Wright, 1983). Tides are semidiurnal with maximum tide ranges close to $2 \mathrm{~m}$. More detailed characteristics of this area are described in Postma (1983).

Collections were made at the diurnal mid-tide time (three hours after the high tide). Three specific microhabitats were sampled at each collection: (1) ten replicates of upper $0.5 \mathrm{~m}$ water column, (2) five replicates of back-swash water and (3) seven replicates of swash sediment. Water-column samples were taken in the immediate proximity of wave breaking, immediately after a wave broke. Backswash water and swash-sediment samples were taken about two seconds after swash water started retreating down the beach. Water samples were taken with PET plastic bottles $\left(1.4 \mathrm{dm}^{3}\right.$ of capacity and $3 \mathrm{~cm}$ diameter opening) due to the fact that the harsh conditions did not allow the use of hydrographic bottles. Sediment samples were taken with plastic corers $\left(0-5 \mathrm{~cm}\right.$ depth, $\left.33 \mathrm{~cm}^{3}\right)$. Water and sediment samples were taken at random distances (1-3.5 m) from each other covering a long-shore distance of ca. $15 \mathrm{~m}$.

Water samples were filtered through a $42 \mu \mathrm{m}$ sieve and fauna retained in the sieve was removed to $200 \mathrm{~cm}^{3}$ plastic jars. Sediment samples were stored in $200 \mathrm{~cm}^{3}$ plastic jars. Sediment and water samples were refrigerated at ca. $7^{\circ} \mathrm{C}$ with $40-100 \mu \mathrm{g}$ of menthol (used as an anaesthetic) and Rose Bengal. To extract the meiofauna from sediment samples, filtered seawater was added to each sample, which was stirred and later decanted for less than 8 seconds in a plastic graduated cylinder $(6.4 \mathrm{~cm}$ diameter, $33 \mathrm{~cm}$ length). After decantation, the supernatant was filtered through a $42 \mu \mathrm{m}$ sieve (Pfannkuche and Thiel, 1988). This procedure was repeated six times. The meiofauna was sorted to major taxa with an inverted microscope $(82 \mathrm{x})$ in a modified Bogorov zooplankton tray.

The height of breaking waves was measured with a graduated pole $(n>30)$. The wave period (measured with a stopwatch) was the time interval between sequential breaking waves $(n>30)$. Temperature of the sediment $(1 \mathrm{~cm}$ of depth) and of the overlying seawater was measured with an alcohol thermometer (precision, $0.5^{\circ} \mathrm{C}$ ).

\section{Statistical analysis}

Environmental and abundance data generally showed significant deviations from a normal distribution (evaluated with Kolmogorov-Smirnov test 
with Lilliefors correction at $\alpha=0.05$ ). Therefore, the non-parametric Kruskal-Wallis test (at $\alpha=0.05$ ) was used to judge if there were differences among collections (according to Sachs, 1982).

Three ratios were calculated with the average densities (numbers $\mathrm{dm}^{-3}$ ) of each major taxa: (1) seawater/sediment ratio $=$ density in seawater $/$ (density in seawater + density in sediment), (2) seawater/swash ratio $=$ density in seawater $/($ density in seawater + density in back-swash water), and (3) swash/sediment ratio = density in backswash water / (density in back-swash water + density in sediment). Significant relations between the average values $(n=9)$ of major taxa abundances and the three ratios described above with wave height and wave period were tested (at $\alpha=0.05$, with sequential Bonferroni correction; Holm, 1979) using linear and quadratic regressions. The variables whose average values of abundances showed no normal distribution (evaluated by the Shapiro-Wilk test) were transformed according to Sokal and Rohlf (1980). Kolmogorov-Smirnov and Shapiro-Wilk tests were carried out with SPSS for Windows, the Kruskal-Wallis test with SigmaStat for Windows and regression analyses with SigmaPlot for Windows.

\section{RESULTS}

\section{The physical environment}

Wave height varied between $22 \pm 6$ and $88 \pm 24 \mathrm{~cm}$ $($ mean \pm SD). The period varied between $4.6 \pm 0.9$ and $6.9 \pm 1.7 \mathrm{~s}$. Temperature at the sediment was the same as the overlying seawater and varied between 16 and $18^{\circ} \mathrm{C}$. Significant differences among collections were found in wave height (Kruskal-Wallis: $\mathrm{p}<0.001)$ and period (K-W: $\mathrm{p}<0.001)$.

\section{Composition and abundance of meiofauna}

Meiofauna found in the water column samples was primarily represented by nauplii (average densities of 17.7-38.1 ind $\left.\mathrm{dm}^{-3}\right)$, bivalve larvae (0-6.4 ind $\left.\mathrm{dm}^{-3}\right)$, harpacticoid copepods (0-1.6 ind $\left.\mathrm{dm}^{-3}\right)$, nematodes (0-1.0 ind $\left.\mathrm{dm}^{-3}\right)$, ostracods $\left(0-0.6 \mathrm{ind} \mathrm{dm}^{-}\right.$ $\left.{ }^{3}\right)$ and platyhelminthes $\left(0-0.2\right.$ ind $\left.\mathrm{dm}^{-3}\right)$. Tardigrades, interstitial polychaetes and crustacean larvae (not nauplii) were also found in lower densities. Cyclopoid copepods were found with average densities of 5.4-45.8 ind $\mathrm{dm}^{-3}$. Significant differences among collections were found in water column densities of nematodes, harpacticoid copepods, nauplii, ostracods, bivalve larvae and platyhelminthes (Kruskal-Wallis: $\mathrm{p}<0.05,<0.001,<0.001,<0.001$, $<0.001$ and $<0.001$ respectively).

Meiofauna found in the back-swash water samples was primarily represented by nauplii (1.7-31.3 ind $\left.\mathrm{dm}^{-3}\right)$, nematodes $\left(0.3-7.9\right.$ ind $\left.\mathrm{dm}^{-3}\right)$, bivalve larvae (0-5.0 ind $\left.\mathrm{dm}^{-3}\right)$, harpacticoid copepods (0-3.6 ind $\left.\mathrm{dm}^{-3}\right)$, platyhelminthes (0-3.3 ind $\left.\mathrm{dm}^{-3}\right)$ and ostracods $\left(0-0.4\right.$ ind $\left.\mathrm{dm}^{-3}\right)$. Tardigrades, interstitial polychaetes and crustacean larvae (not nauplii) were also found in lower densities. Cyclopoid copepods were found with average densities of 2.7-50.8 ind $\mathrm{dm}^{-3}$. Significant differences among collections were found in back-swash water densities of nematodes, harpacticoid copepods, nauplii, ostracods, bivalve larvae and platyhelminthes (Kruskal-Wallis: $\mathrm{p}<0.001,<0.01,<0.01,<0.001,<0.001$ and $<0.05$ respectively).

Meiofauna found in the sediment samples was primarily represented by nauplii (0-169.1 ind 100 $\left.\mathrm{cm}^{-3}\right)$, nematodes $\left(9.0-37.8\right.$ ind $\left.100 \mathrm{~cm}^{-3}\right)$, platyhelminthes (2.15-38.7 ind $\left.100 \mathrm{~cm}^{-3}\right)$, harpacticoid copepods (0-94.2 ind $\left.100 \mathrm{~cm}^{-3}\right)$, ostracods $(0-31.4$ ind $\left.100 \mathrm{~cm}^{-3}\right)$ and bivalve larvae $(0-1.3$ ind 100 $\left.\mathrm{cm}^{-3}\right)$. Cyclopoid copepods, tardigrades, interstitial polychaetes and gastrotrichs were also found in lower densities. Significant differences among collections were found in sediment densities of nematodes, harpacticoid copepods, nauplii, bivalve larvae, ostracods and platyhelminthes (Kruskal-Wallis: $\mathrm{p}<0.05,<0.001,<0.001,<0.01,<0.001$ and $<0.05$ respectively).

\section{Variability of meiofaunal densities}

Figures 1 and 2 show the biplots of the average water column and swash densities of the most abundant meiofaunal major taxa vs. wave height and wave period (cyclopoid copepods were not included due to the fact that they are restricted to a planktonic life; Giere, 1993). A significant trend was found between the density of harpacticoids in swash water and wave period $\left(\mathrm{Y}_{\mathrm{adj}}=26.4-10 \mathrm{x}+0.96 \mathrm{x}^{2}, \mathrm{r}^{2}=0.68\right.$, $\mathrm{p}<0.05$, power $\mathrm{r}_{\alpha=0.05}=0.82$ ). Excepting the preceding trend, no significant linear or quadratic trends (at $\alpha=0.05$ ) were found among average values of meiofaunal densities with wave height or wave period. No significant linear or quadratic trends (at $\alpha=0.05$ ) were found among values of the density ratios (seawater/sediment, seawater/swash and swash/sedi- 
Nematoda

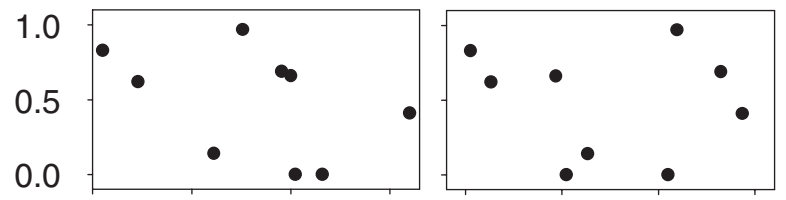

Harpacticoidea

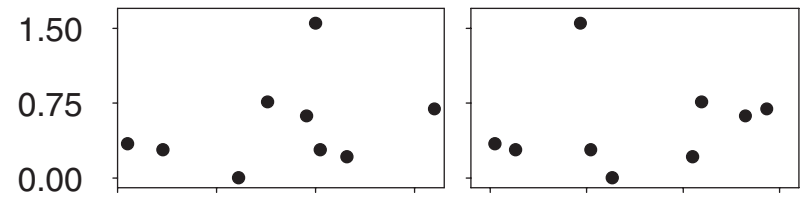

Nauplii

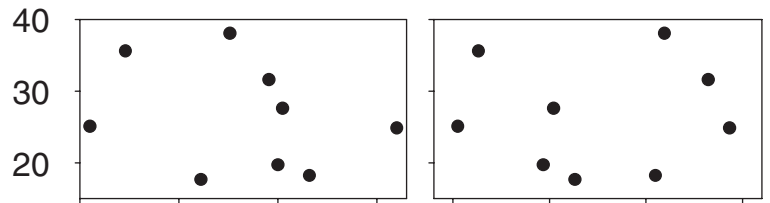

Platyhelminthes
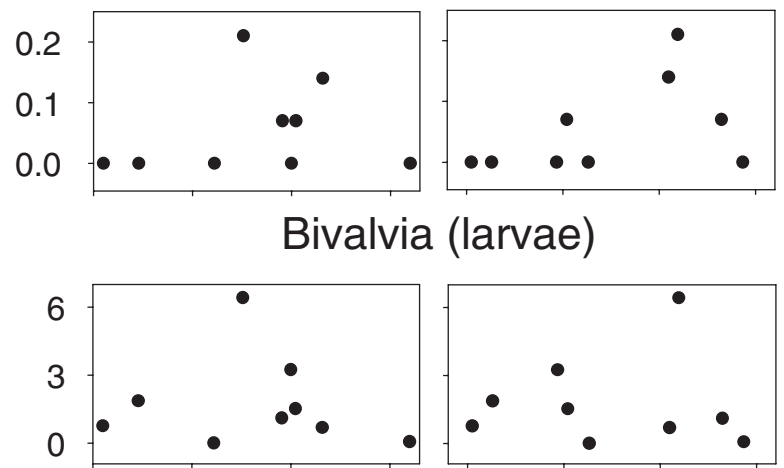

Ostracoda

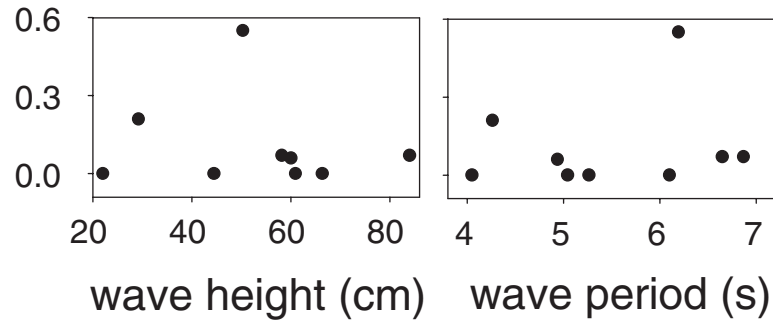

FIG. 1. - Biplots of average densities in the column water of the major groups of the meiofauna (ind $\mathrm{dm}^{-3}$ ) versus the average wave height $(\mathrm{cm})$ and period $(\mathrm{s})$.

ment) of nematodes, harpacticoid copepods, nauplii, platyhelminthes, ostracods or bivalve larvae with wave height or wave period.

Figure 3 shows the biplots of densities of major meiofaunal taxa in the seawater vs. densities in the back-swash water and densities in the sediment. No significant linear or quadratic trends (at $\alpha=0.05$ ) were found.
Nematoda

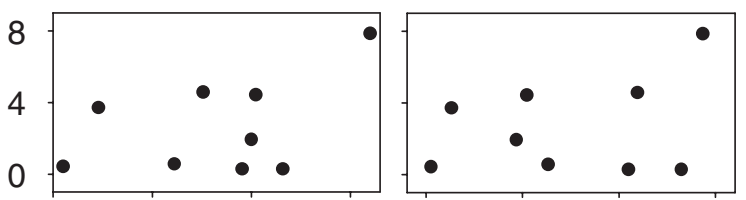

Harpacticoidea

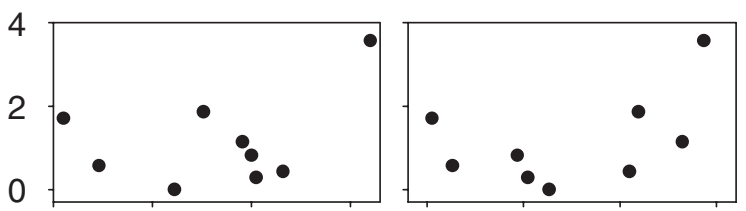

Nauplii

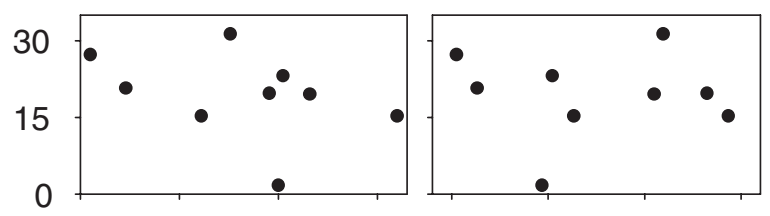

Platyhelminthes

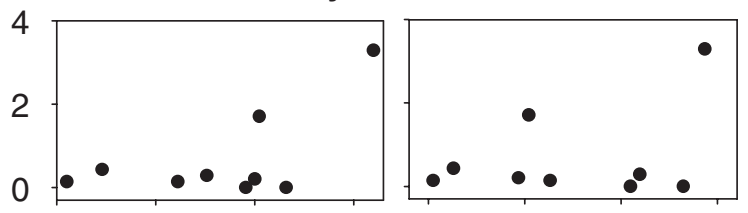

Bivalvia (larvae)

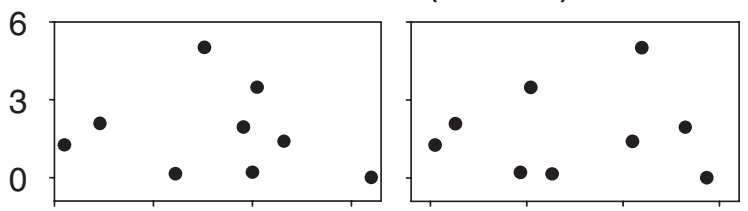

Ostracoda

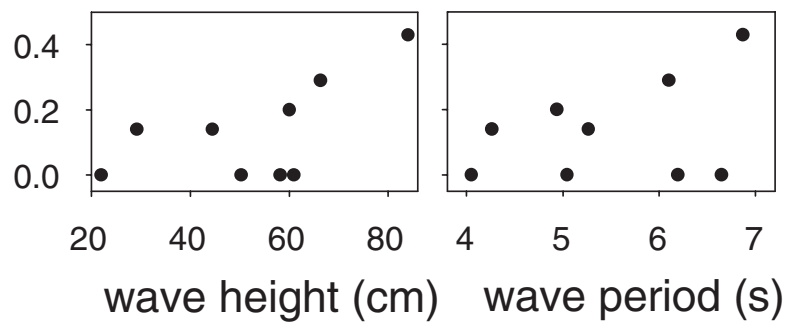

FIG. 2. - Biplots of average densities in the back-swash water of the major groups of the meiofauna (ind $\mathrm{dm}^{-3}$ ) versus the average wave height $(\mathrm{cm})$ and period $(\mathrm{s})$.

\section{DISCUSSION}

\section{Sampling design}

The usual field methods for estimating meiofaunal emergence rates (emergence traps and plankton nets) were not used due to the hardness of the swash zone. Thus, instead of emergence rates, density 

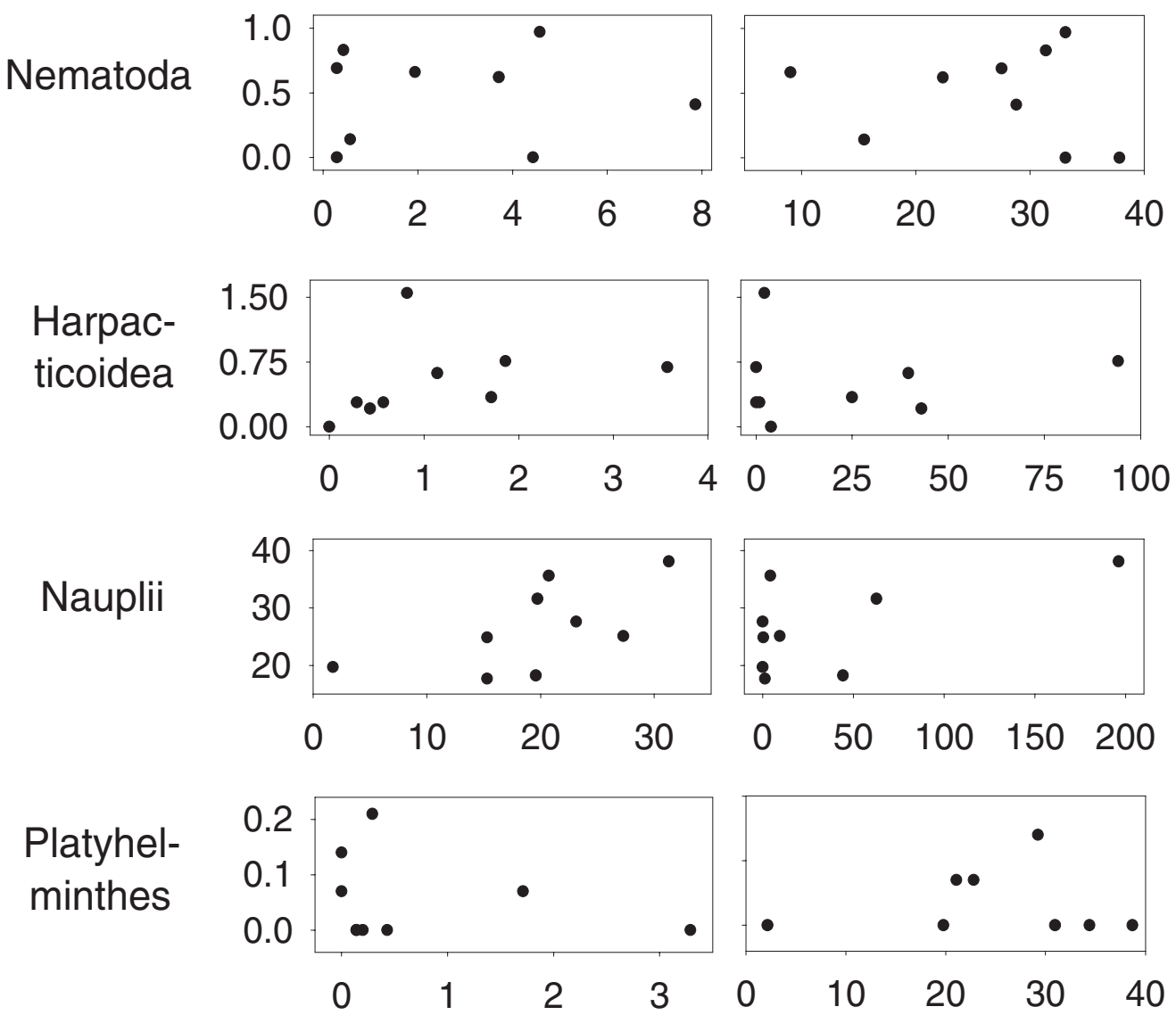

Bivalvia (larvae)
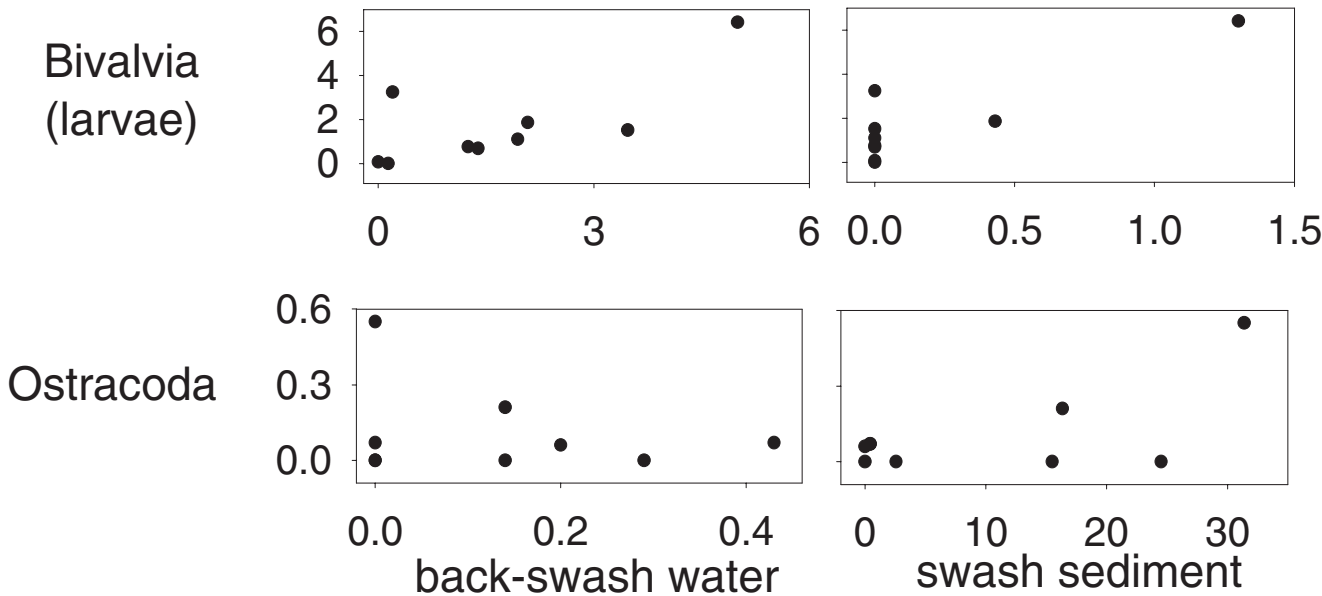

FIG. 3. - Biplots of average densities in the column water of the major groups of the meiofauna (ind dm ${ }^{-3}$ ) versus the average densities in the back-swash water (ind $\mathrm{dm}^{-3}$ ) and swash sediment (ind $100 \mathrm{~cm}^{-3}$ ).

ratios were used as an indirect estimation. Densities in the water column not only depend on diurnal emergence (mainly passive, Armonies, 1988a, 1994), but also on nocturnal emergence (passive and active, Armonies, 1994). Thus, density ratios are less useful than emergence rates to study passive emergence because densities in the water column may also be influenced by active emergence. Moreover, lunar phase and temperature varied among sampling dates, and these are two factors potentially influencing active emergence of meiofauna (Armonies, 1994). Therefore, this sampling design is useful to study a possible correlation between meiofaunal emergence and wave characteristics in two cases: (1) with meiofaunal taxa which do not exhibit active emergence, and (2) if wave action is the predominant factor influencing meiofaunal emergence. 


\section{Variability of meiofaunal densities}

Results showed that although significant differences were found in meiofaunal water column densities among samplings, no significant trends with wave characteristics were found. Moreover, figure 3 showed that meiofaunal densities of sediment, swash water and water column were not correlated. A priori, a positive correlation between water column and swash water densities was expected, due to the winnowing effect of the wave action. Among the major taxa found in the water column, Nematoda is the only group that laboratory studies showed does not actively emerge and has a positive correlation between water column density and current velocity (and sediment erosion rate; Armonies, 1988a, 1988b). According to the comments above this taxon is valid to check the Armonies's prediction with this sampling design. Therefore, in the range of 21-84 $\mathrm{cm}$ of average breaking height, wave climate did not explain daily variability of meiofaunal densities present at the water column and backswash water.

Nevertheless, Armonies's prediction must not be rejected, because these results may not be extrapolated to other intertidal habitats. Reflective beaches with coarse grain size harbour well oxygenated sediment and meiofauna is not limited in vertical distribution (McLachlan and Turner, 1994), i.e., meiofauna has a relatively high vertical mobility in the sediment. In other soft bottom environments (e.g. intertidal flats and sheltered beaches with fine grain size), meiofauna has a more limited vertical distribution in the sediment due to the presence of a relatively superficial anoxic sediment layer (Berninger and Epstein, 1995; Giere, 1993; Moodley et al., 1997). Therefore, in these environments with limited vertical distribution, meiofauna is more exposed to the erosive action of waves, while in reflective exposed beaches (as sampled in this study) meiofauna may migrate deeper into the sediment to avoid wave action. This vertical migration can be examined in future works studying the vertical distribution of the meiofauna in the sediment vs. wave energy. Moreover the morphodynamic state of the sandy beaches (sensu Short and Wright, 1983) may play an important role in the passive emergence of meiofauna because relative wave energy and sediment transport increase from reflective to dissipative beaches whereas grain size decreases (Short, 1999).

Due to the importance of emergence in the meiofaunal populations (Armonies, 1994), more studies in beaches and other habitats are required to check the potential influence of wave action in this process. Ideally, future research should take into account the vertical distribution of meiofauna covering a wide gradient of morphodynamic states.

\section{ACKNOWLEDGEMENTS}

This study was supported at Germany by a grant of the Secretaría Xeral de Investigación e Desenvolvemento (Xunta de Galicia). Special thanks to Norma Hernández, Iris Menn and Alejandro Rodríguez, and Alfred-Wegener-Institut für Polarund Meeresforschung, Wattenmeerstation Sylt for working facilities and sampling assistance. This research was supported by the Xunta de Galicia (XUGA 30105A98) and the Universidade de Vigo (XUNTA-UVI 64502C130). Iam Emmett corrected the English text.

\section{REFERENCES}

Armonies, W. - 1988. Physical factors influencing active emergence of meiofauna from boreal intertidal sediment. Mar. Ecol. Prog. Ser., 49(3): 277-286.

Armonies, W. - 1988. Hydrodynamic factors affecting behaviour of intertidal meiobenthos. Ophelia, 28(3): 183-193.

Armonies, W. - 1994. Drifting meio- and macrobenthic invertebrates on tidal flats in Königshafen: a review. Helgoländer Meeresuntersuchungen, 48: 299-320.

Berninger, U.G. and S.S. Epstein. - 1995. Vertical distribution of benthic ciliates in response to the oxygen concentration in an intertidal North Sea sediment. Aquat. Microb. Ecol., 9(3): 229236.

Brown, A.C. and A. McLachlan. - 1990. Ecology of sandy shores. Elsevier Science, Amsterdam.

Eckman, J.E. - 1983. Hydrodynamic process affecting benthic recruitment. Limnol. Oceanogr., 28(2): 241-257.

Folk, R.L. - 1980. Petrology of sedimentary rocks. Hemphill, Austin, Texas.

Giere, O. - 1993. Meiobenthology. The Microscopic Fauna in Aquatic Sediments. Berlin-Heidelberg.

Holm, S. - 1979. A simple sequentially rejective multiple test procedure. Scand. J. Stat., 6: 65-70.

McLachlan, A. - 1983. Sandy beach ecology. A review. In: A. McLachlan and T. Erasmus (eds.), Sandy Beaches as Ecosystems, pp. 321-380. Junk, The Hague.

McLachlan, A., E. Jaramillo, T.E. Donn and F. Wessels. - 1993. Sandy beach macrofauna communities and their control by the physical environment: a geographical comparison. J. Coast. Res., 15: 27-38.

McLachlan, A. and I. Turner. - 1994. The interstitial environment of sandy beaches. Mar. Ecol., 15(3/4): 177-211.

McLachlan, A., A. de Ruyck and N. Hacking. - 1996. Community structure on sandy beach: patterns of richness and zonation in relation to tide range and latitude. Rev. Chil. Hist. Nat., 69: 451467.

Moodley, L., G.J. van der Zwaan, P.M.J.Herman, L. Kempers and P. van Breugel. - 1997. Differential response of benthic meiofauna to anoxia with special reference to Foraminifera (Protista: Sacordina). Mar. Ecol. Prog. Ser., 158: 151-163.

Palmer, M.A. - 1986. Hydrodynamics and structure: Interactive effects on meiofauna dispersal. J. Exp. Mar. Biol. Ecol., 104: 53-68. 
Palmer, M.A. and R.Molloy. - 1986. Water flow and the vertical distribution of meiofauna: A flume experiment. Estuaries, 9(3): 225-228.

Palmer, M.A. - 1988. Epibenthic predators and marine meiofauna: Separating predation, disturbance, and hydrodynamic effects. Ecology, 69(4): 1251-1259.

Pfannkuche, O. and H. Thiel. - 1988. Sample processing. In: R.P. Higgins and $\mathrm{H}$. Thiel (eds.), Introduction to the study of meiofauna, pp. 134-145. Smithsonian Institution Press, London.

Postma, H. - 1983. Hydrography of the Wadden Sea: Movements and properties of water and particulate matter. In: W.J. Wolff (ed.), Ecology of the Wadden Sea. Vol. 1, report 2, pp. 1-221.
A.A. Balkema, Rotterdam.

Sachs, L. - 1982. Applied statistics: a handbook of techniques. Springer, New York

Short, A.D. and L.D. Wright. - 1983. Physical variability of sandy beaches. In: A. McLachlan and T. Erasmus (eds.), Sandy beaches as ecosystems, pp. 133-144. W. Junk, The Hague.

Short, A.D. - 1999. Wave-dominated beaches. In: A.D. Short (ed.), Handbook of beach and shoreface morphodynamics, pp. 173203. John Wiley, Chichester.

Sokal, R.R. and F.J. Rohlf. - 1980. Introducción a la Bioestadística. Reverté, Barcelona. 
